\title{
The effect of meteorological and chemical parameters on summer phytoplankton assemblages in an urban recreational lake
}

\author{
Jelena Jovanović ${ }^{1}$, Ivana Trbojević ${ }^{1}$, Gordana Subakov Simić ${ }^{1}$, Sladjana Popović ${ }^{3}$, Dragana \\ Predojević $^{1}$, Ana Blagojević ${ }^{4}$ and Vesna Karadžić ${ }^{2 *}$ \\ ${ }^{1}$ University of Belgrade, Faculty of Biology, Studentski trg 16, 11000 Belgrade, Serbia \\ 2 Institute of Public Health of Serbia "Dr Milan Jovanović Batut", Dr Subotića 5, 11000 Belgrade, Serbia \\ ${ }^{3}$ University of Belgrade, Institute of Chemistry, Technology and Metallurgy, Department of Ecology and Technoeconomics, \\ Karnegijeva 4, 11000 Belgrade, Serbia \\ ${ }^{4}$ Institute of Public Health of Belgrade, Boulevard of Despot Stefan 54a, 11000 Belgrade, Serbia
}

\begin{abstract}
The summer phytoplankton community was studied across both vertical and temporal scales in relation to environmental factors in the shallow recreational Sava Lake. The sampling was conducted weekly at four depths from mid-July until mid-September 2014, in order to detect short-term changes within the assemblages. Besides physical and chemical parameters, meteorological data was also included in the investigation, as that year was characterized with extreme rainfall, which caused serious flooding in the region. The community succession was characterized by a reverse in the cyanobacteria (Codon M) and chlorococcal green algae (Coda F and J). Statistical analyses (RDA) indicated that changes in the community composition and successional pattern could have been due to the mixing regime variations in the reservoir, most likely induced by weather disturbances, especially high precipitation and wind events. These events did not permit massive cyanobacterial development, although they most likely caused resuspension of dissolved phosphorus from the sediment. When observing functional groups, three groups could be distinguished by their response to the above-mentioned parameters: the first prefers high temperature and insolation ( $\mathrm{Lm}, \mathrm{Y}, \mathrm{Lo}, \mathrm{Xph}, \mathrm{W} 2$ and $\mathrm{M})$, the second is correlated with precipitation and wind (Td, C, K, MP and X2), while the third group tolerates cloudiness (H1, F, N, X1, D, J and P).
\end{abstract}

Keywords: phytoplankton / succession / meteorological parameters / cyanobacteria / Sava Lake

Résumé - Les effets des paramètres météorologiques et chimiques sur les assemblages phytoplanctoniques estivaux dans un lac récréatif urbain. La communauté estivale de phytoplancton a été étudiée à l'échelle verticale et temporelle en relation avec des facteurs environnementaux dans le lac Sava, récréatif peu profond. L'échantillonnage a été effectué chaque semaine à quatre profondeurs, de la mi-juillet à la mi-septembre 2014, afin de détecter les changements à court terme au sein des assemblages. Outre les paramètres physiques et chimiques, les données météorologiques ont également été prises en compte dans l'étude, car cette année-là, les précipitations ont été extrêmes, ce qui a provoqué de graves inondations dans la région. La succession des communautés a été caractérisée par une inversion des cyanobactéries (Codon $\mathrm{M})$ et des algues vertes chlorococciques (Coda $\mathrm{F}$ et $\mathrm{J}$ ). Les analyses statistiques (RDA) ont indiqué que les changements dans la composition de la communauté et le modèle de succession pourraient être attribuables aux variations du régime de mélange dans le réservoir, très probablement causé par les perturbations météorologiques, en particulier les fortes précipitations et les épisodes de vent. Ces événements n'ont pas permis le développement massif de cyanobactéries, bien qu'ils aient très probablement causé une remise en suspension du phosphore dissous dans les sédiments. Lors de l'observation des groupes fonctionnels, trois groupes peuvent être distingués par leur réponse aux paramètres susmentionnés: le premier préfère les températures élevées et l'insolation ( $\mathrm{Lm}, \mathrm{Y}, \mathrm{Lo}, \mathrm{Xph}, \mathrm{W} 2$ et $\mathrm{M}$ ), le second est corrélé aux précipitations et au vent ( $\mathrm{Td}, \mathrm{C}, \mathrm{K}, \mathrm{K}, \mathrm{MP}$ et $\mathrm{X} 2)$, tandis que le troisième groupe tolère la nébulosité (H1, F, N, X1, D, J et P).

Mots-clés : phytoplancton / succession / paramètres météorologiques / cyanobactéries / lac Sava

\footnotetext{
*Corresponding author: vesna_karadzic@batut.org.rs
} 


\section{Introduction}

In natural conditions, phytoplankton species generally respond to environmental changes (physical, chemical, and biological), such as water light intensity, temperature and nutrients (Ma et al., 2015). Furthermore, the summer phytoplankton of a lake, particularly some species, is considered to be a reliable indicator of its trophic status (Grabowska et al., 2013).

Each phytoplankton group (taxonomical or functional) has unique features which allow it to predominate at a different time period within the year and under specific environmental conditions in an aquatic ecosystem. Consequently, as conditions change, which is usually related to seasonal shifts, one group gives way to another in the process of succession (Reynolds, 1980; Rosen and St. Amand, 2015). In eutrophic reservoirs, summer phytoplankton is mostly dominated by cyanobacteria or green algae, although diatoms can prevail in the case of high disturbances of the water column (Znachor et al., 2008). In recent years, there has been an increasing number of ecological studies that use morpho-functional classifications of phytoplankton for environmental research rather than taxonomical units, considering that this approach provides results that are more comparable (Žutinić et al., 2014). Based on this principle, species are grouped in functional groups called Codons (Padisák et al., 2009).

The elements that are widely considered as crucial for phytoplankton development in aquatic ecosystems are macronutrients nitrogen and phosphorus (Rhee and Gotham, 1981; Zohary et al., 2010), as well as silica for diatoms (Suthers and Rissik, 2008). Furthermore, the community composition changes with depth, season and latitude (Rhee and Gotham, 1981). In this regard, not only do chemical factors and internal (autogenic) processes influence the phytoplankton succession, but also external disturbances affect the structure and distribution of phytoplankton, e.g. rainfall or wind-induced mixing, which can result in nutrient inputs or cause the dilution of a portion of the phytoplankton biomass (Znachor et al., 2008). In fact, meteorological conditions (as external factors) are especially important, bearing in mind that they influence temporal community changes, as well as vertical phytoplankton distribution. Therefore, combined studies can provide a basis for early warning methods when it comes to algal blooms (Bresciani et al., 2013; Ma et al., 2015), particularly blooms of cyanobacteria that produce toxins. In comparison to other algae, cyanobacteria generally prefer non-turbulent conditions in a water column, which enables them to float towards the water surface using specific buoyancy regulation mechanisms (Suthers and Rissik, 2008). Consequently, disturbances that cause changes in the vertical mixing regime, can alter the competitive balance between cyanobacteria and other phytoplankton species that sink more easily (Beaver et al., 2013).

It is important to note that succession of phytoplankton communities is an autogenic process that is driven by environmental changes which occur as a result of the aquatic ecosystem metabolism. Nevertheless, some disturbancedriven changes can distort the succession pattern and thus affect the stability of aquatic communities (Honti et al., 2007). The effect of the events that cause disturbances in phytoplankton development (which includes high flushing rates after heavy rainfall) has mainly been observed trough laboratory experiments. Field studies are less common, bearing in mind that these events are not easy to predict (Znachor et al., 2008).

Phytoplankton dynamics have been the subject of numerous studies (e.g. Häggqvist and Lindholm, 2012; Laskar and Gupta, 2013; Žutinić et al., 2014) and most of them focus on changes observed through seasonal or monthly analysis. However, in order to understand the shift in phytoplankton communities more precisely, it is necessary to observe their dynamics on a weekly, or even daily basis. The aim of this study was to investigate the summer dynamics of phytoplankton in the shallow, urban Sava Lake (Serbia), used mainly for recreational purposes, in relation to internal and external ecological parameters. The investigation was conducted on a weekly basis in order to detect short-term changes in this community during the bathing season. Special attention was paid to the dynamics of cyanobacteria, given their negative impact on public health when it comes to recreational waters.

\section{Materials and methods}

\subsection{The study area}

The Sava Lake is an urban reservoir, created in 1967 by embanking the armlet of the Sava River. Located in Čukarica, a municipality of Belgrade City, it is situated approximately $4 \mathrm{~km}$ upstream from the confluence of the Sava and Danube rivers. It stretches between the right bank of the Sava River and the river island called Ada Ciganlija, covering an area of about 90 ha (Fig. 1, right). The reservoir is supplied with water filtered through a sedimentation unit built on its southern bank. This water body has an estimated volume of $4000000 \mathrm{~m}^{3}$, the length of the reservoir is $4.4 \mathrm{~km}$, while the average width is approximately $250 \mathrm{~m}$. It is generally shallow, as the maximum recorded depth is $12 \mathrm{~m}$ and the average depth is $4.5 \mathrm{~m}$. It is mainly used for recreational purposes (Mićković et al., 2014), but it is used as an additional source of water supply, as well. For this reason, the reservoir is periodically cleaned in order to maintain good water quality (Blaženčić, 1995).

The lake is surrounded by Salix alba L., Populus alba L. and Quercus robur L. trees, the shores are covered with gravel, while the bottom of the reservoir is covered with a combination of mud/sand or mud/clay (Blaženčić, 1995).

Sampling was conducted at 4 depths, always at the same locality $\left(\mathrm{N} 44^{\circ} 47^{\prime} 17.42^{\prime \prime}\right.$, E20 $\left.24^{\prime} 44.24^{\prime \prime}\right)$, where a research station buoy was fixed (Fig. 1, left).

\subsection{Fieldwork and phytoplankton analysis}

A Ruttner Water Sampler (volume 1 L) was used on site for taking samples for chemical, Chlorophyll- $a$ (Chl- $a$ ) and quantitative phytoplankton analysis. The sampling was conducted weekly from July 13th until September 9th, 2014, which included a total of 9 weeks (W1-W9). The samples for phytoplankton quantification were collected from 4 depths $(0,2,4$ and $6 \mathrm{~m})$, put into plastic bottles and preserved in Lugol's solution (at ratio 1:100) according to the European standard en 15204 (2006). Additionally, the samples for qualitative phytoplankton analysis were taken using a plankton net (mesh size $22-23 \mu \mathrm{m}$, net frame $25 \mathrm{~cm} \varnothing$ ) from the bottom up to the surface of the water body. Water temperature and 


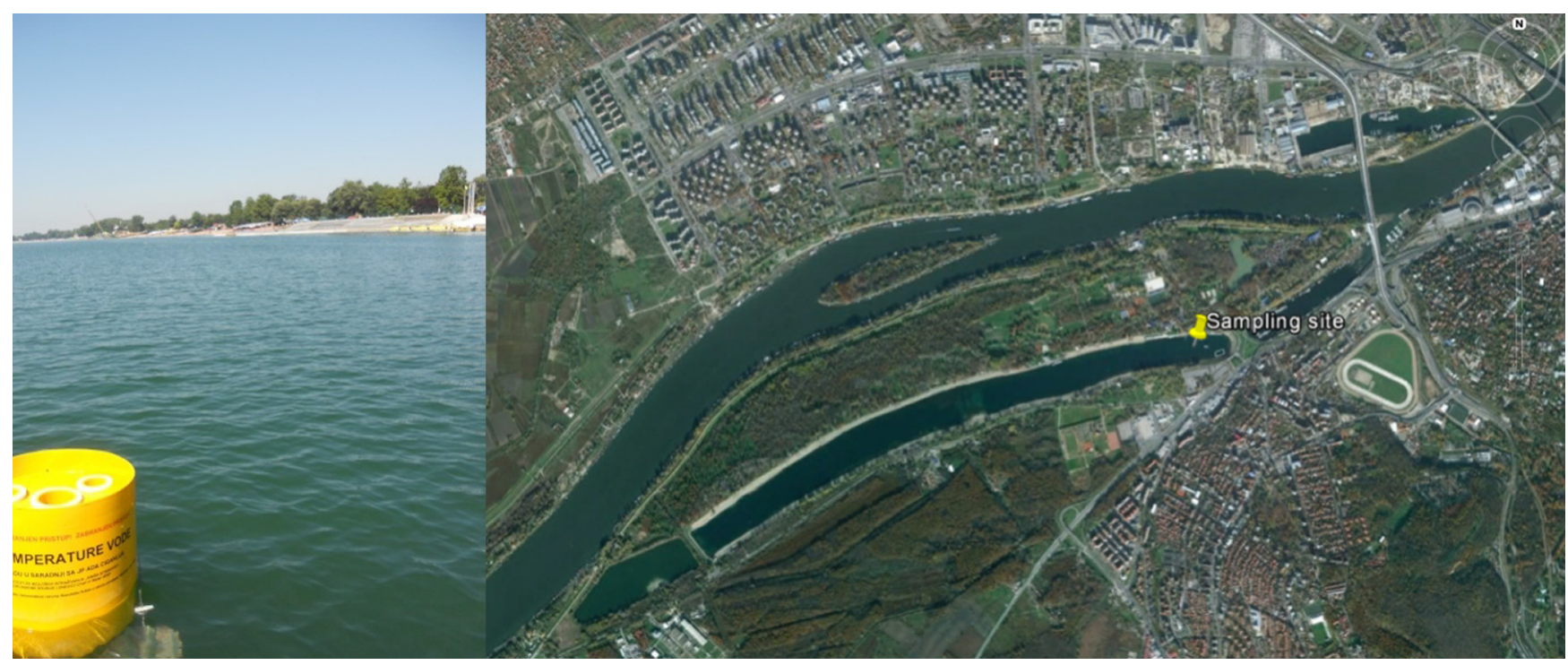

Fig. 1. The Sava Lake reservoir, satellite image of a sampling site (right) and photograph of the locality (left).

transparency were measured in situ using a thermometer and a Secchi disk, respectively.

Quantitative phytoplankton analysis was carried out following the Utermöhl method (European standard SRPS en 15204:2008) on a Zeiss Axio Observer.Z1 inverted microscope, which was connected to a digital camera and the size measuring program ZenPro 2. Standard keys were used for identification of phytoplankton species. The data were expressed as a number of individuals and cells per milliliter. Additionally, measured dimensions of about 25 individuals were used for the calculation of phytoplankton biomass by using the standard formula (Hillebrand et al., 1999; Sun and Liu, 2003) and were expressed in $\mu \mathrm{g}$ per liter. Phytoplankton diversity was calculated using the Shannon index (Shannon and Weaver, 1949). A classification presented by Reynolds et al. (2002) and Padisák et al. (2009) was used to analyze the dynamics of the phytoplankton functional groups in relation to the environmental parameters.

\subsection{Chemical analysis}

The standard spectrophotometric method (ISO 10260:1992 (E)) was used to determine the concentration of Chl- $a$ in the water and the values were expressed in micrograms per liter $(\mu \mathrm{g} / \mathrm{L})$. The analysis was conducted the same day (soon after they were taken) at the Laboratory of Algology, Mycology and Lichenology, the Institute of Botany and Botanical Garden "Jevremovac" (Belgrade).

Along with the samples of phytoplankton and Chl- $a$, samples for chemical analysis were taken (at depths 0,4 and $6 \mathrm{~m}$, according to Official Gazette of the RS 74/2011) and sent to the laboratory for water analysis at the Institute of Public Health "Dr Milan Jovanović Batut", where standard methods were used to examine the main chemical parameters for algal growth.

\subsection{Data analysis}

Statistical analyses (RDA) were conducted using the CANOCO program, Version 5.0 (Ter Braak and Šmilauer,
2012). The first RDA analysis was performed to illustrate the summer dynamic of phytoplankton in the Sava Lake. The sampling months (July, August and September) were used as explanatory variables, while sampling weeks and depths were used as supplementary variables. In this analysis, we decided to show the dynamics of the phytoplankton taxonomic groups: Cyanobacteria (divided into Chroococcales, Oscillatoriales and Nostocales), Chlorophyta, Bacillariophyta, Euglenophyta, Dinophyta, Cryptophyta and Chrysophyta. The initial data included the number of cells of all the recorded taxa, after which each taxon was assigned to a taxonomic group that was used in the analysis instead of individual taxa. RDA with the option "center and standardize" was used.

A second RDA analysis was performed to examine the relationship of the physical and meteorological parameters on the cyanobacterial and algal community (biovolume was used as a measure) presented as phytoplankton functional groups. The phytoplankton functional groups that were greater than $1 \%$ of the biomass content in more than one sample were used in the analysis (Codons: B, C, D, F, J, K, Lm, Lo, M, MP, N, P, Td, Y, $\mathrm{X} 1, \mathrm{X} 2, \mathrm{Xph}$ and $\mathrm{W} 2)$. Transparency, water temperature, insolation, precipitation, wind and cloudiness were included as explanatory variables, while sampling months, weeks and Chlorophyll- $a$ were included as supplementary variables. Air temperature and the average daily temperature were initially also used, but due to correlation with water temperature, all three parameters were submitted to the interactive forward selection, after which the water temperature was included in final RDA. RDA with the option "center and standardize" was used.

Data for all the observed meteorological parameters were taken from the Meteorological yearbooks of Serbia (The Republic Hydrometeorological Institute of Serbia, 2014, 2015).

\section{Results}

\subsection{External environmental factors}

With regard to the meteorological events, 2014 was mostly characterized by extreme rainfall, which caused massive 
Table 1. Chemical parameters measured in the Sava Lake during summer of 2014.

\begin{tabular}{|c|c|c|c|c|c|c|c|c|c|}
\hline \multirow{2}{*}{$\begin{array}{l}\text { Month } \\
\text { Week }\end{array}$} & \multicolumn{3}{|c|}{ July } & \multicolumn{3}{|c|}{ August } & \multicolumn{3}{|c|}{ September } \\
\hline & W1 & W2 & W3 & W4 & W5 & W6 & W7 & W8 & W9 \\
\hline $\begin{array}{l}\text { Water column } \\
\text { (m) }\end{array}$ & $0-6 \mathrm{~m}$ & $0-6 \mathrm{~m}$ & $0-6 \mathrm{~m}$ & $0-6 \mathrm{~m}$ & $0-6 \mathrm{~m}$ & $0-6 \mathrm{~m}$ & $0-6 \mathrm{~m}$ & $0-6 \mathrm{~m}$ & $0-6 \mathrm{~m}$ \\
\hline $\begin{array}{l}\text { Turbidity } \\
\text { (NTU) }\end{array}$ & $1-2.56$ & $0.98-1.94$ & $0.98-1.40$ & $1.08-1.80$ & $1.28-1.43$ & $1.25-3.17$ & $0.95-1.33$ & $1.14-1.38$ & $0.96-1.10$ \\
\hline $\mathrm{pH}$ & $8.18-8.41$ & $8.03-8.09$ & $7.29-7.77$ & $7.49-7.63$ & $7.75-8.03$ & $7.44-8.11$ & $7.76-7.84$ & $8.15-8.24$ & $8.03-8.17$ \\
\hline $\begin{array}{l}\text { Conductivity } \\
(\mu \mathrm{S} / \mathrm{cm})\end{array}$ & $233-238$ & $226-242$ & $222-237$ & $223-225$ & $217-222$ & $213-214$ & 219-222 & 219-222 & $223-224$ \\
\hline $\begin{array}{l}\text { Ammonia } \\
(\mathrm{mg} / \mathrm{L})\end{array}$ & $\begin{array}{l}0.0521- \\
0.0622\end{array}$ & $\begin{array}{l}0.0541- \\
0.0606\end{array}$ & $\begin{array}{l}0.0449- \\
0.0706\end{array}$ & $\begin{array}{l}0.0256- \\
0.0575\end{array}$ & $\begin{array}{l}0.0271- \\
0.0490\end{array}$ & $\begin{array}{l}0.0162- \\
0.0233\end{array}$ & $\begin{array}{l}0.0526- \\
0.0658\end{array}$ & $\begin{array}{l}0.0675- \\
0.0707\end{array}$ & $\begin{array}{l}0.0401- \\
0.0460\end{array}$ \\
\hline $\begin{array}{l}\text { Nitrites } \\
(\mathrm{mg} / \mathrm{L})\end{array}$ & $\begin{array}{l}0.0049- \\
0.0082\end{array}$ & $\begin{array}{l}0.0036- \\
0.0049\end{array}$ & $\begin{array}{l}0.0013- \\
0.0026\end{array}$ & $\begin{array}{l}0.0007- \\
0.0043\end{array}$ & $\begin{array}{l}0.0007- \\
0.0033\end{array}$ & $\begin{array}{l}0.0010- \\
0.0099\end{array}$ & $\begin{array}{l}0.0016- \\
0.0033\end{array}$ & $\begin{array}{l}0.0020- \\
0.0026\end{array}$ & $\begin{array}{l}0.0020- \\
0.0033\end{array}$ \\
\hline $\begin{array}{l}\text { Nitrates } \\
(\mathrm{mg} / \mathrm{L})\end{array}$ & $\begin{array}{l}0.0022- \\
0.0123\end{array}$ & $\begin{array}{l}0.0461- \\
0.2657\end{array}$ & 0.0022 & $\begin{array}{l}0.0022- \\
0.1164\end{array}$ & $\begin{array}{l}0.2920- \\
0.4501\end{array}$ & $\begin{array}{l}0.0022- \\
0.0198\end{array}$ & $\begin{array}{l}0.0022- \\
0.0123\end{array}$ & 0.0022 & $\begin{array}{l}0.0022- \\
0.0044\end{array}$ \\
\hline $\begin{array}{l}\text { Dissolved } \\
\text { inorganic } \\
\text { nitrogen } \\
(\mathrm{mg} / \mathrm{L})\end{array}$ & $\begin{array}{l}0.0608- \\
0.0711\end{array}$ & $\begin{array}{l}0.0759- \\
0.1231\end{array}$ & $\begin{array}{l}0.0470- \\
0.0737\end{array}$ & $\begin{array}{l}0.0368- \\
0.0623\end{array}$ & $\begin{array}{l}0.0981- \\
0.1425\end{array}$ & $\begin{array}{l}0.0217- \\
0.0280\end{array}$ & $\begin{array}{l}0.0565- \\
0.0690\end{array}$ & $\begin{array}{l}0.0708- \\
0.0739\end{array}$ & $\begin{array}{l}0.0439- \\
0.0485\end{array}$ \\
\hline $\begin{array}{l}\text { Orthophosphate } \\
(\mathrm{mg} / \mathrm{L})\end{array}$ & $\begin{array}{l}0.0018- \\
0.0064\end{array}$ & $\begin{array}{l}0.0015- \\
0.0026\end{array}$ & $\begin{array}{l}0.0432- \\
0.0579\end{array}$ & $\begin{array}{l}0.0003- \\
0.0432\end{array}$ & $\begin{array}{l}0.0030- \\
0.0040\end{array}$ & $\begin{array}{l}0.0006- \\
0.0013\end{array}$ & $\begin{array}{l}0.0380- \\
0.1726\end{array}$ & $\begin{array}{l}0.0026- \\
0.0392\end{array}$ & $\begin{array}{l}0.0022- \\
0.0192\end{array}$ \\
\hline $\begin{array}{l}\text { Total phosphorus } \\
(\mathrm{mg} / \mathrm{L})\end{array}$ & $\begin{array}{l}0.0097- \\
0.0192\end{array}$ & $\begin{array}{l}0.0086- \\
0.0111\end{array}$ & $\begin{array}{l}0.0624- \\
0.0772\end{array}$ & $\begin{array}{l}0.0092- \\
0.0591\end{array}$ & $\begin{array}{l}0.0073- \\
0.0092\end{array}$ & $\begin{array}{l}0.0105- \\
0.0124\end{array}$ & $\begin{array}{l}0.0739 \\
0.2014\end{array}$ & $\begin{array}{l}0.0120- \\
0.0714\end{array}$ & $\begin{array}{l}0.0299- \\
0.0379\end{array}$ \\
\hline $\begin{array}{l}\text { Permanganate index } \\
(\mathrm{mg} / \mathrm{mL})\end{array}$ & $8.3-10.2$ & $7.4-8.3$ & $5.4-6.7$ & $6.9-7.3$ & $7.9-11.7$ & $10.7-11.7$ & $10.1-11.0$ & $10.1-11.4$ & $8.5-8.8$ \\
\hline $\mathrm{SiO}_{2}$ & - & $\begin{array}{l}0.46- \\
0.68\end{array}$ & $\begin{array}{l}0.0910- \\
0.1336\end{array}$ & $\begin{array}{l}0.2639- \\
0.3903\end{array}$ & $\begin{array}{l}0.4150- \\
0.4780\end{array}$ & $\begin{array}{l}0.3830- \\
0.8060\end{array}$ & $\begin{array}{l}0.3000- \\
0.5780\end{array}$ & $\begin{array}{l}0.3810- \\
0.6220\end{array}$ & $\begin{array}{l}0.5850- \\
0.8110\end{array}$ \\
\hline $\begin{array}{l}\text { Dissolved oxygen } \\
(\mathrm{mg} / \mathrm{L})\end{array}$ & $\begin{array}{l}11.4- \\
12.4\end{array}$ & $\begin{array}{l}10.50- \\
12.80\end{array}$ & $\begin{array}{l}8.50- \\
9.80\end{array}$ & $\begin{array}{l}8.70- \\
9.10\end{array}$ & $\begin{array}{l}8.7- \\
10.20\end{array}$ & $\begin{array}{l}9.00- \\
9.50\end{array}$ & $\begin{array}{l}10.70- \\
11.40\end{array}$ & $\begin{array}{l}9.60- \\
10.00\end{array}$ & $\begin{array}{l}8.40- \\
10.70\end{array}$ \\
\hline BOD & $\begin{array}{l}1.5- \\
2.5\end{array}$ & $\begin{array}{l}4.00- \\
4.50\end{array}$ & $\begin{array}{l}1.60- \\
2.10\end{array}$ & $\begin{array}{l}1.70- \\
2.70\end{array}$ & $\begin{array}{l}1.30- \\
1.80\end{array}$ & $\begin{array}{l}1.30- \\
3.20\end{array}$ & $\begin{array}{l}5.50- \\
6.10\end{array}$ & $\begin{array}{l}1.50- \\
3.10\end{array}$ & $\begin{array}{l}1.00- \\
3.00\end{array}$ \\
\hline $\begin{array}{l}\text { Chlorophyll- } a \\
(\mu \mathrm{g} / \mathrm{L})\end{array}$ & $\begin{array}{l}5.49- \\
6.10\end{array}$ & $\begin{array}{l}3.66- \\
5.49\end{array}$ & $\begin{array}{l}4.88- \\
6.10\end{array}$ & $\begin{array}{l}6.10- \\
7.93\end{array}$ & $\begin{array}{l}2.36- \\
8.30\end{array}$ & $\begin{array}{l}5.49- \\
9.15\end{array}$ & $\begin{array}{l}6.10- \\
8.54\end{array}$ & $\begin{array}{l}7.93- \\
8.54\end{array}$ & $\begin{array}{l}7.93- \\
10.37\end{array}$ \\
\hline
\end{tabular}

flooding in most parts of Serbia. According to the measurements given by the Republic Hydrometeorological Institute of Serbia (2013, 2014) for Belgrade (station Košutnjak, Čukarica), total precipitation in $2014(1015.5 \mathrm{~mm})$ was almost twice as great as the previous year $(586.0 \mathrm{~mm})$. The highest peak was observed in May $(291.1 \mathrm{~mm})$, which is often the month with the highest precipitation, considering that a moderate continental climate is predominant in Serbia. However, another peak that occurred in July $(187.3 \mathrm{~mm}$ in total) was unexpected, as it occurred in the (generally dryer) summer period. The mean annual temperature was somewhat higher $\left(13.6^{\circ} \mathrm{C}\right)$ than the previous year $\left(13.3^{\circ} \mathrm{C}\right)$, although the mean temperatures, temperature maximums and daily temperature amplitudes for the summer months were lower.

Our research was conducted in the summer period between the events of exceptionally high rainfall in July, and also later in September. During the study period, precipitation was the highest at the end of July/beginning of August (in the 4th week $-\mathrm{W} 4$, with an average daily precipitation of $13.9 \mathrm{~mm}$ ), while in the next week it was observed as the lowest $(2.6 \mathrm{~mm})$. The peak of precipitation was followed by the peak of the average wind speed $(2.4 \mathrm{~m} / \mathrm{s})$. Additionally, the wind speed reached another peak $(2.4 \mathrm{~m} / \mathrm{s})$ in the 7 th week of our investigation (the end of August). The average air temperature varied with a slightly decreasing trend $\left(26.5-19.9^{\circ} \mathrm{C}\right)$, and the highest recorded was in late July (W3). Insolation varied the most (12.6-5.2 h), although the greatest peak and the lowest value coincided with the average air temperature extremes (W3) for the investigated period.

\subsection{Internal environmental factors}

During the study period, water temperature varied between 24 and $27^{\circ} \mathrm{C}$, reaching the highest values at the end of July and mid-August, while transparency was the highest in mid-July $(3.5 \mathrm{~m})$ and the lowest $(2.5 \mathrm{~m})$ at the end of our study period, $i$. $e$. in September.

The results of the chemical analysis are presented in Table 1, showing the range of variation within the water column for each investigated week. It should be noted that the lowest turbidity was recorded within the 7 th week of our research at a depth of $6 \mathrm{~m}$, while the highest value of this 
Table 2. Phytoplankton diversity and predominant taxa in The Sava Lake in summer of 2014.

\begin{tabular}{|c|c|c|c|}
\hline Division & Genera & Taxa & The most frequent Taxa within each division \\
\hline Cyanobacteria & 19 & 30 & $\begin{array}{l}\text { Aphanocapsa holsatica, Chroococcus minutus, Geitlerinema amphibium, } \\
\text { Microcystis aeruginosa, Pseudanabaena catenata }\end{array}$ \\
\hline Dinophyta & 4 & 7 & Ceratium hirundinella, Peridinium spp., Peridiniopsis cunningtonii \\
\hline Chrysophyta & 1 & 1 & Dinobryon divergens \\
\hline Cryptophyta & 2 & 6 & Cryptomonas spp., Rhodomonas minuta \\
\hline Bacillariophyta & 9 & 22 & Cyclotella sp., Fragilaria sp. \\
\hline Chlorophyta & 34 & 98 & $\begin{array}{l}\text { Coelastrum microporum, Cosmarium spp., Eutetramorus fottii, } \\
\text { Oocystis spp., Pediastrum simplex, Scenedesmus spp., Tetraedron minimum }\end{array}$ \\
\hline Euglenophyta & 2 & 8 & Euglena spp., Trachelomonas spp. \\
\hline Total & 71 & 172 & \\
\hline
\end{tabular}

a

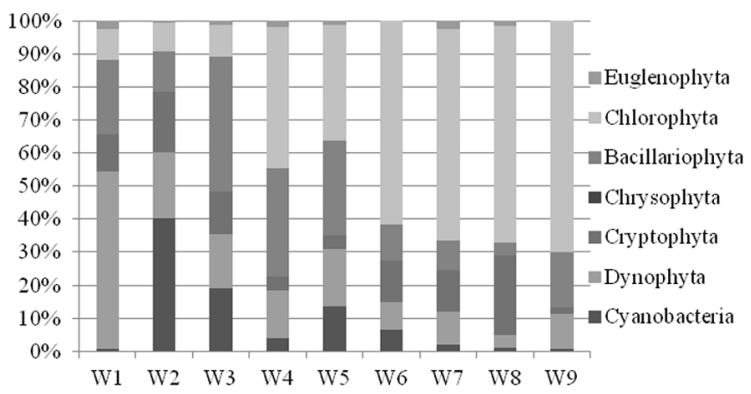

$\mathrm{b}$

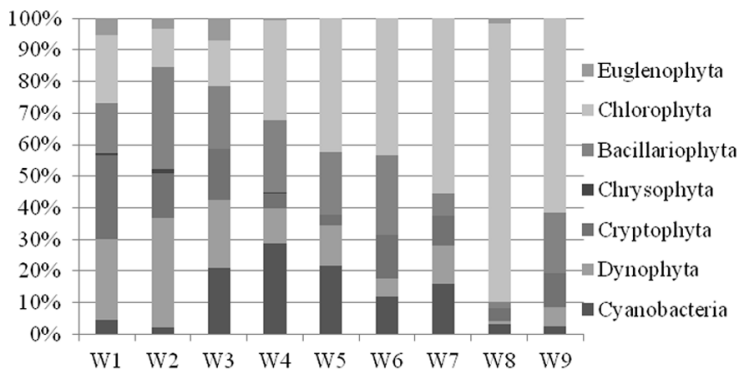

$\mathrm{c}$

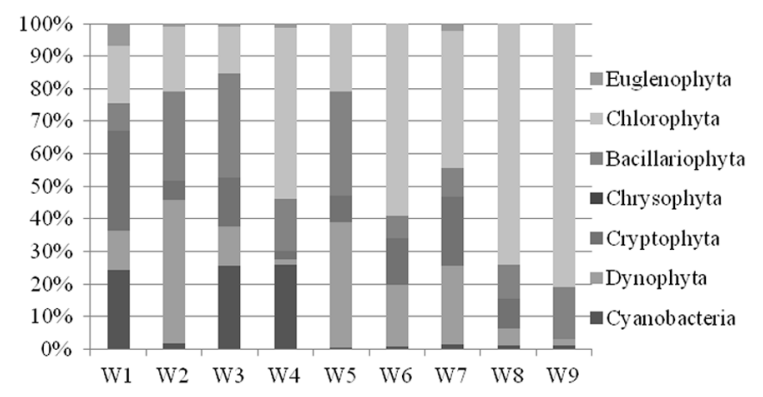

d

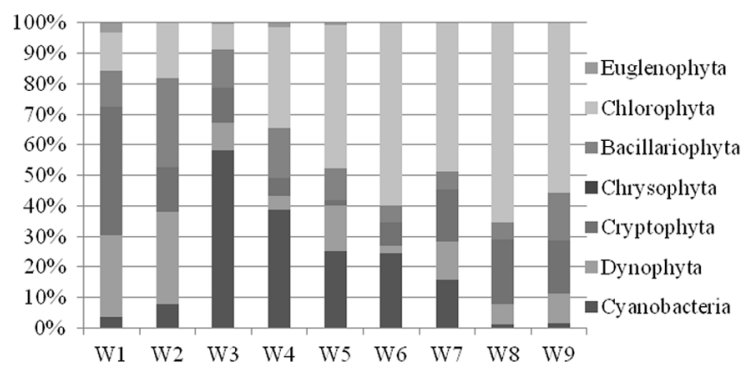

Fig. 2. Temporal dynamic of phytoplankton in the Sava Lake, expressed as the proportion of algal biomass at $0 \mathrm{~m}$ (a), $2 \mathrm{~m}$ (b), $4 \mathrm{~m}$ (c) and $6 \mathrm{~m}(\mathrm{~d})$. parameter was observed the week before at water surface. Conductivity and $\mathrm{pH}$ varied slightly, both having lowest values in the 3rd week, although at different depths. In general, $\mathrm{pH}$ varied from neutral (7.29) to slightly alkaline (8.41), and the later was recorded in the first week of the research at a depth of $6 \mathrm{~m}$. The nutrients were relatively low for this type of water body, bearing in mind that it was the bathing season. This especially refers to nitrates, which were generally low and almost below the level of detection at the end of July and August, as well as in September. However, in mid-August (W5) nitrates reached $0.45 \mathrm{mg} / \mathrm{L}$ at a depth of $4 \mathrm{~m}$. Ammonia ranged from $0.0162 \mathrm{mg} / \mathrm{L}$ (W6 at $0 \mathrm{~m}$ ) to $0.0707 \mathrm{mg} / \mathrm{L}$ (W8 at $4 \mathrm{~m}$ ), while nitrites were between 0.0007 (W5 at $0 \mathrm{~m}$ ) and 0.0099 (W6 at $6 \mathrm{~m}$ ) mg/L. Orthophosphates and total phosphorus varied the greatest at a depth of $4 \mathrm{~m}$, both reaching their maximum at the end of August (W7). Minimal values of orthophosphates were observed in the first week of August (W4), followed by a decline in total phosphorus, which reached its minimum in the following week. On the other hand, the concentration of silica varied greatly in the water column, however, a significant decrease was observed in late July.

There was an increasing trend in the organic matter, presented using Permanganate index, towards the end of the study. A similar trend was noticed for Chlorophyll- $a$ concentration, which reached a concentration of $10.37 \mu \mathrm{g} / \mathrm{L}$ by the end of the study (at $6 \mathrm{~m}$ depth). In mid-August (W5), however, a considerable drop in biomass was noticed, especially at a depth of $4 \mathrm{~m}$. This coincides with the decrease in total phosphorus, as well as orthophosphates the previous week.

The concentration of dissolved oxygen was the highest at the beginning of the study (in July) and had a slightly decreasing trend by the end of August, when a rise in concentration was noted again. Biochemical oxygen demand (BOD) was mostly low, except in the last weeks of July and August.

\subsection{The composition of the phytoplankton community in the Sava Lake}

A total of 172 taxa, belonging to 7 divisions, were detected during the study (Tab. 2). The most diverse group was Chlorophyta with $57 \%$ of the identified taxa, followed by 
Cyanobacteria (17.4\%) and Bacillaryophyta (12.8\%), while other groups were considerably less diverse.

With regard to the number of cells, chroococcalean cyanobacteria Aphanocapsa holsatica (Lemmermann) G. Cronberg \& Komárek, was mostly observed as the dominant species in July. At the end of July (from the 3rd week of our research), a shift was recorded where Microcystis aeruginosa became dominant. Its predominance lasted until the end of August, when it was succeeded by chlorococalean green algae Oocystis spp. (O. lacustris Chodat, O. marssonii Lemmermann, O. borgei J.W. Snow), and Tetraëdron minimum (A. Braun) Hansgirg later in September.

Nevertheless, when biomass is taken into account, in the first two weeks of the study Cryptomonas Ehrenberg spp. (C. caudata Massart, $C$. ovata Ehrenberg), Ceratium hirundinella (O.F. Müller) Dujardin and Peridinium Ehrenberg sp. were mostly dominant, as they are species much larger than $A$. holsatica (Lemmermann). Also, in the first week of August, the filamentous green alga Mougeotia C. Agardh sp. prevailed over the $M$. aeruginosa biomass, but it was replaced by $O$. borgei by the end of August.

Throughout the whole study period, the littoral zone was densely covered with macrophytes, among which Myriophyllum spicatum L. was always dominant.

\subsection{Temporal and spatial variations of phytoplankton assemblages (abundance, biomass, and diversity index)}

The temporal dynamics of the phytoplankton community, presented as a proportion of the algal biomass at each of the investigated depths (Fig. 2), shows that the percentage of Chlorophyta had increased throughout the study period at all the investigated depths, while the percentage of Bacillariophyta was the highest in July. Dinophyta was dominant within the community in the first week at the water surface layer and the next week at the other three depths. Later, in general, the decrease in this trend was noticed. Cryptophyta were also the most abundant at the beginning of the study, especially at depths of 4 and $6 \mathrm{~m}$. The greatest variation with regard to depth was noticed for Cyanobacteria. At the water surface, this group was the most abundant in the 2nd week, while in the following two weeks it reached its highest numbers at depth of $6 \mathrm{~m}$. Nevertheless, when the total number of cells for each division was taken into account, Cyanobacteria were observed to be the dominant group at almost all depths until the end of August, when they were succeeded by green algae.

The first performed RDA analysis (Fig. 3), which included a sampling month as an explanatory variable and the phytoplankton community divided into taxonomic groups as the response data, showed statistical significance of $F=8$, $P=0.0002$. The first RDA axis explained a $29.96 \%$ variability in our data. Sampling months were distributed along the first axis in the following way: July was placed on the left side of the ordination diagram, August in the middle and September on the right side. The first two weeks of August (W4 and W5) were placed on the left, while the last two weeks (W6 and W7) were placed on the right side of the ordination diagram. Eukaryotic algae and cyanobacteria showed that their dynamics were connected with sampling time. Two groups can be easily distinguished on the ordination diagram, but more precisely: Chrysophyta, Dinophyta, Euglenophyta and Cryptophyta had the highest cell numbers in July, Bacillariophyta in July and August, and Chlorophyta in September. Cyanobacteria were unequally distributed: Chroococcales were frequently encountered during July, Oscillatoriales almost equal in all months and Nostocales in September. All depths (D0, D2, D4), except the depth of $6 \mathrm{~m}$ (D6), were similar in terms of cyanobacterial and algal cells. D6 stands out because of Chroococcales group that was the most numerous at this depth.

With regard to the Shannon index, the lowest diversity of the phytoplankton community $(0.98)$ was observed in the second half of July (W2) at a depth of $6 \mathrm{~m}$, and the highest $(2,75)$ in mid-August (W6) at a depth of $4 \mathrm{~m}$.

\subsection{Phytoplankton functional groups in correlation with environmental factors}

All the identified phytoplankton species were sorted into 25 functional groups (Codons). Codons $\mathrm{J}$ and $\mathrm{F}$ were the most diverse, with 35 and 32 species, respectively. At the beginning of the study, Codons $\mathrm{Y}$ and Lo had the highest biomass, however, in the next week Codon $M$ was recorded as subdominant (along with Y) and, by the end of July, it became dominant. Its dominance continued in August, followed by an increasing biomass of Codon $\mathrm{T}$, represented only by one species from the genus Mougeotia, which most likely emerged from periphyton. Nevertheless, they were succeeded by Codon $\mathrm{F}$ at the end of this month. On the other hand, if we observe the number of cells, Codon $\mathrm{K}$ was dominant component in the community in July, as well as Codon $\mathrm{J}$ later in August and September.

A multivariate analysis of the functional groups and the chemical parameters did not show clear correlations and therefore was not presented in this section. However, RDA that included meteorological parameters singled out factors that are possibly the most responsible for the changes in the summer community (Fig. 4).

Transparency, water temperature and insolation showed a negative correlation, while cloudiness positively correlated with the first RDA axis, which explained a $21.87 \%$ variability in our data. Precipitation and wind negatively correlated with the second RDA axis ( $r=-0.4527, r=-0.6340$, respectively). The analysis showed a statistical significance of $F=3.2$, $P=0.0002$. Three groups of phytoplankton functional groups were distinguished: group 1-Lm, Y, Lo, Xph, W2 and M, which correlated with variables that show negative correlation with the first RDA axis; group 2-Td, C, K, MP and X2, which correlated with precipitation and wind, and group 3-H1, F, N, $\mathrm{X} 1, \mathrm{D}, \mathrm{J}$ and $\mathrm{P}$, which correlated with cloudiness. According to the RDA, the 10 codons that fitted best were: W2, B, M, C, Lo, $\mathrm{X} 1, \mathrm{~N}, \mathrm{~F}, \mathrm{~J}$ and $\mathrm{H} 1$. Also, group 1 had the highest biomass in July and group 3 later in summer and in September (Fig. 4).

\subsection{The summer dynamic of potentially toxic $\mathbf{M}$. aeruginosa in The Sava Lake}

When observing Cyanobacteria, it can be observed (Fig. 5, upper) that species from the order Chroococcales had the 
J. Jovanović et al.: Knowl. Manag. Aquat. Ecosyst. 2017, 418, 48

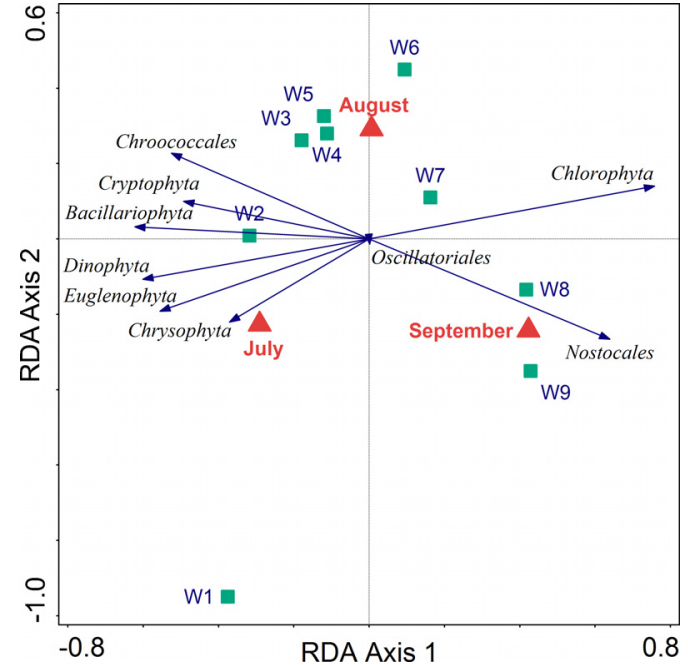

Fig. 3. RDA analysis of summer phytoplankton dynamic in the Sava Lake.

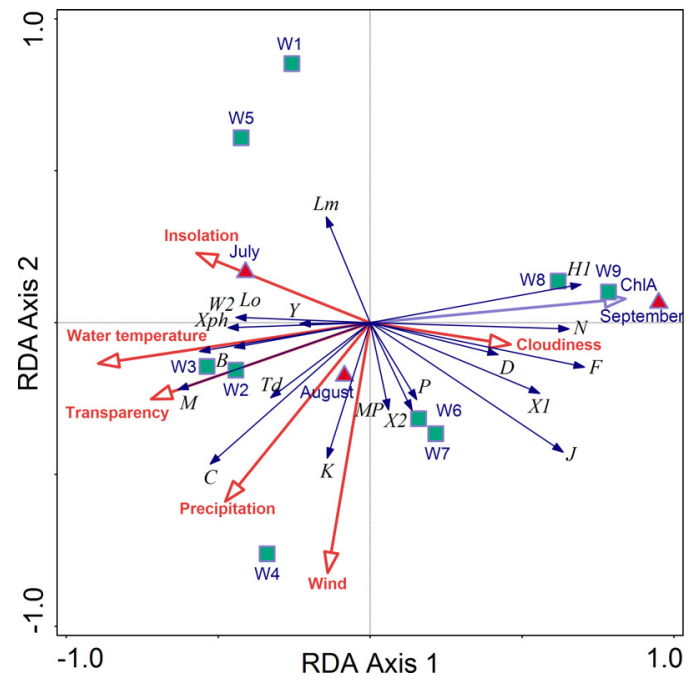

Fig. 4. RDA analysis of functional groups and physical/meteorological parameters in the Sava Lake.
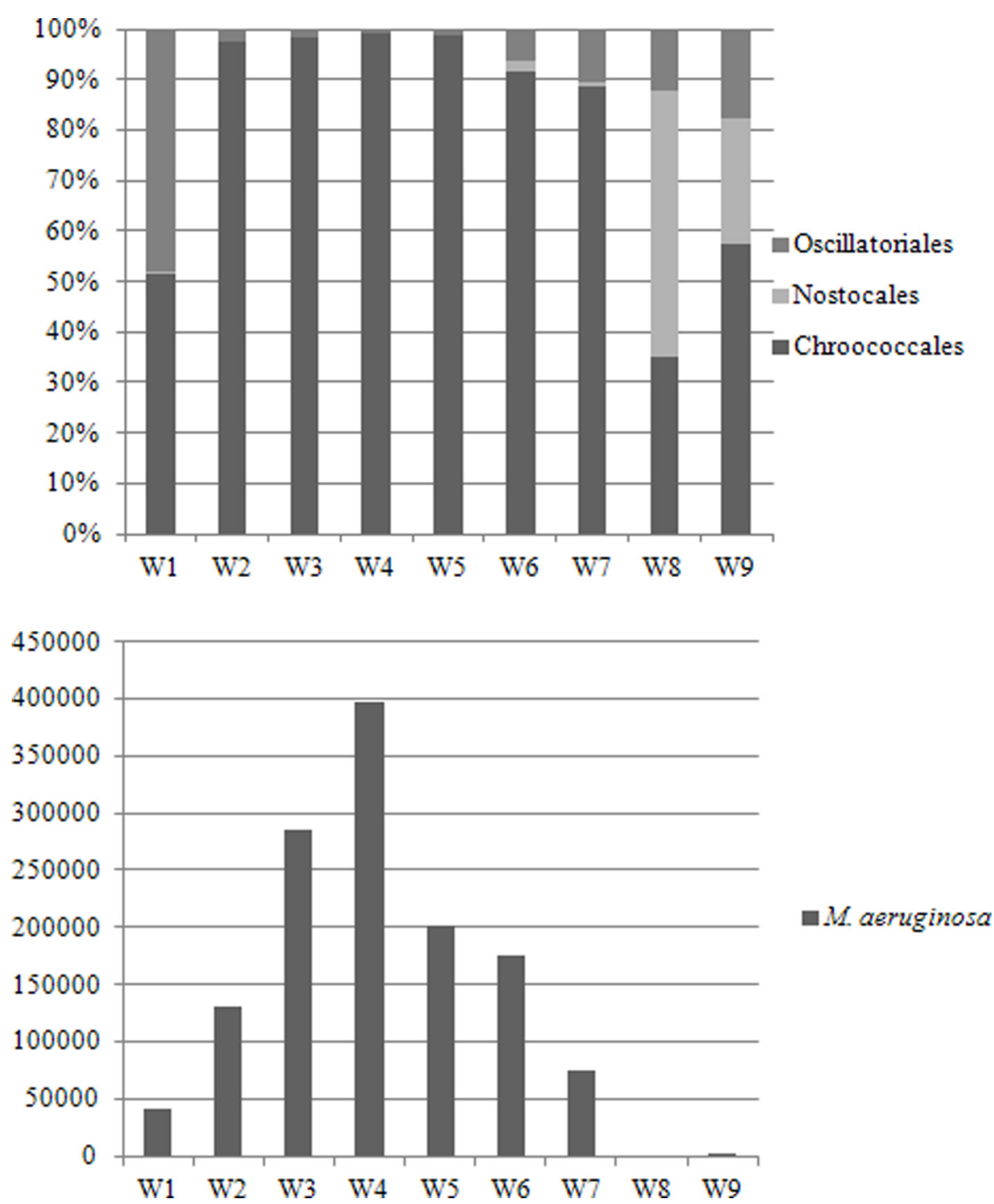

Fig. 5. Proportion of different cyanobacterial groups and temporal dynamic of Microcystis aeruginosa in the Sava Lake, summer 2014. 


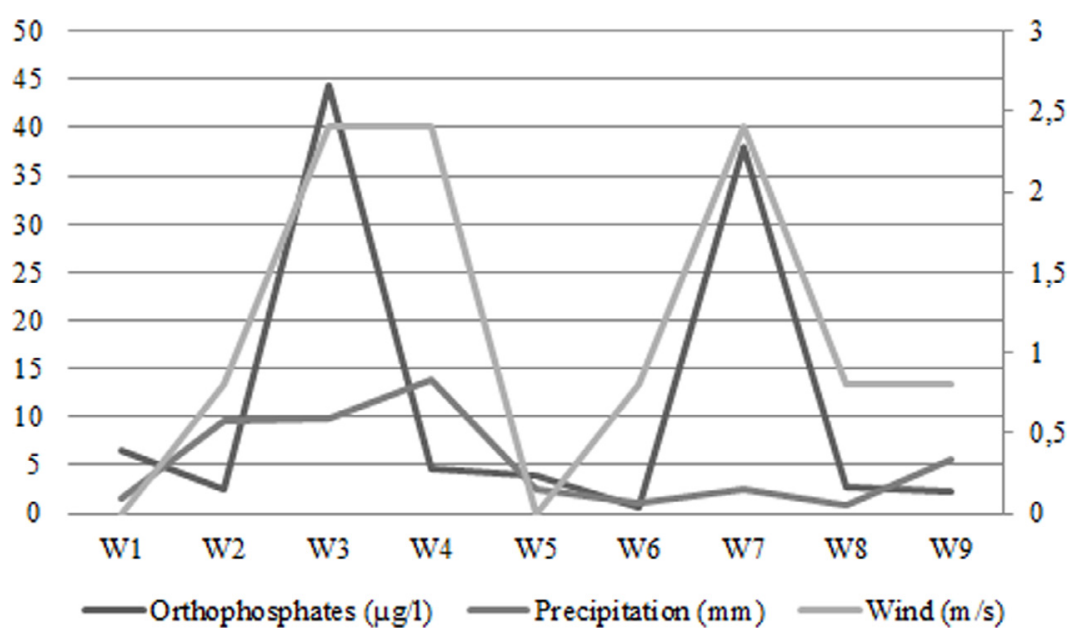

Fig. 6. The relationship between concentration of orthophosphates, precipitation (First Axis) and wind (Second Axis).

highest biomass in July and August and a major proportion of this biomass belonged to $M$. aeruginosa. Figure 5 (down) shows that $M$. aeruginosa reached the peak of its biomass in the 1st week of August, with the highest concentration at a depth of $4 \mathrm{~m}\left(6.04 \times 10^{5} \mu \mathrm{g} / \mathrm{L}\right)$ and an average value of $3.97 \times 10^{5} \mu \mathrm{g} / \mathrm{L}$ in the entire water column. In the next period, however, a decreasing trend in its abundance was recorded.

It is worth mentioning that in July, a high number of $A$. holsatica cells were noted, although the biomass of this picocyanobacteria was low due to its small dimensions, reaching its maximum in the 2 nd week at a depth of $6 \mathrm{~m}$ $\left(0.17 \times 10^{5} \mu \mathrm{g} / \mathrm{L}, 33264\right.$ cell $\left./ \mathrm{mL}\right)$. Another constantly present chroococcal cyanobacteria was Aphanocapsa coferta, with a biomass ranging from $0.08 \times 10^{3}$ to $8.1 \times 10^{3} \mu \mathrm{g} / \mathrm{L}$ and principally decreasing as September approached.

In general, a number of cyanobacteria ranged between 15 and 33540 cells $/ \mathrm{mL}$, while their biomass varied between $0.02 \times 10^{5}$ and $6.29 \times 10^{5} \mu \mathrm{g} / \mathrm{L}$.

\section{Discussion}

\subsection{Phytoplankton dynamic in relation to physical, chemical and climatic conditions}

During the bathing season of 2014, the phytoplankton community in the Sava Lake was exposed to frequent variations of different environmental factors. This is most likely due to the meteorological conditions, characterized by frequent rainfall that year (Hydrometeorological Institute, 2014), which ultimately (in April, May and September) caused severe torrential flooding in Serbia (Petrović, 2015) and shortened the bathing season period at Ada Ciganlija beach. Today, it is widely considered that in the future, the frequency and intensity of environmental extremes, such as flooding, will increase due to climate change (Bogatov and Fedorovskiy, 2016).

With regard to water quality, Ada Ciganlija is so far the only beach in Serbia awarded with a Blue Flag (Foundation for environmental Education, 2014) and the last published scientific data concerning the trophic status of the Sava Lake indicated that this water body was mesotrophic (MartinovicVitanovic et al., 2010). This was mainly confirmed by the results of the chemical analysis in our study. In general, the results show a good ecological status of the Sava Lake, except in the 7th week of the study (the end of August), when orthophosphates, total phosphorus and BOD had somewhat higher values. This increase in phosphates coincides with a peak in wind strength, which may have caused the mixing and influx of orthophosphates from the sediment (Fig. 6). Bresciani et al. (2013) and Yang et al. (2016b) also suggest that, in shallow lakes, strong winds can lead to sediment resuspension and the enrichment of water with phosphorus. On the other hand, macrophyte can reduce nutrient availability to phytoplankton in the case of excessive use of dissolved nitrogen and phosphorous (Devi et al., 2016).

The phytoplankton community observed in the Sava Lake gradually changed during the course of our research. The dominant phytoplankton taxa shifted from Bacillariophyta and flagellate forms (such as Cryptophyta, Dinophyta), to Cyanobacteria and finally Chlorophyta. Reynolds (1980) noticed that there is a pattern concerning the annual succession of dominant taxa. In his research, he defined general pathways for both eutrophic (diatoms, Volvocales, Nostocales, dinoflagellates/Microcystis shift) and mesotrophic (diatoms, Chrysophyte-Sphaerocystis, dinoflagellates shift) lakes. These seasonal phytoplankton variations are related to the combined effect of many environmental factors (Ren et al., 2014), which include physical, chemical and biological variables. Thus, successional events concerning phytoplankton development are often altered by weather-induced disturbances (Yang et al., 2016a). The studies that followed the influence of physical variables on phytoplankton assemblages started back in the early 1970s, however, phytoplankton ecologists have devoted more attention to nutrient-driven changes, while physical factors have been less frequently observed (Zohary et al., 2010).

In our study, the dominance of Chlorophyta occurred only after the dominance of cyanobacteria $M$. aeruginosa. Such reversion in comparison to the general pattern could be due to the fact that chroococcalean cyanobacteria are considered to be better competitors in comparison to the larger-celled species at lower concentrations of dissolved phosphorus (Suthers and Rissik, 2008). This could also explain why picocyanobacteria A. holsatica had a high number of cells in July. Furthermore, 
picocyanobacteria have a large surface/volume ratio which enables them to absorb depleted nutrients more efficiently (Wood et al., 2017). On the other hand, a relatively high percentage of diatoms in July and August was most likely maintained by water column turbulences caused by extreme weather events.

When assemblages were observed at a vertical scale, some differences were noted, however, RDA analysis did not indicate that these were wide-range variations. In this regard, disturbances caused by wind (or heavy rainfall) can substantially alter the mixing regime (Znachor et al., 2008), and wind velocity above a critical value can induce mixing, which often lead to a relatively uniform distribution of phytoplankton on a vertical scale (Ma et al., 2015). Taking into consideration the weather conditions in the summer of 2014, this was probably the case in the Sava Lake.

Besides a taxonomical perspective, a community response to environmental changes can be investigated from a functional perspective (Cellamare et al., 2016). One of the most commonly used systems was the one created by Reynolds (1980) with initially 14 algal groups, which was later upgraded by Padisák et al. (2009) and supplemented with additional groups (Codons) according to the morphological and physiological characteristics of the species (Borics et al., 2012). The advantage of this functional approach in comparison to traditional taxonomy lies in the fact that it makes environmental investigations more comparable and facilitates the assessment of an ecological response to changing conditions (Žutinić et al., 2014).

Assemblages such as $\mathrm{C}, \mathrm{J}, \mathrm{G}, \mathrm{S} 1, \mathrm{H} 1, \mathrm{H} 2$ and $\mathrm{SN}$ are expected to appear as dominant in the growing season, however, other groups can also be found as dominant (Borics et al., 2012). A generalized succession pattern implies a C-GM-P shift in temperate eutrophic systems and a B-E-L-N shift in mesotrophic systems (Reynolds et al., 2002). According to Padisák et al. (2009), the majority of the identified codons in the Sava Lake are characteristic of eutrophic or mesoeutrophic small- and mediumsized lakes. Statistical analysis of the assemblages and environmental factors indicated that physical parameters in this case might have had a stronger impact on the succession of functional groups than chemical parameters. In this regard, three groups were distinguished in accordance with the observed parameters.

The first group, which had the highest abundance at the beginning of the study and was made up of Codons Lm, Y, Lo, $\mathrm{Xph}, \mathrm{W} 2$ and $\mathrm{M}$, mostly correlated with transparency, insolation and water and air temperature. Generally, this group includes flagellated phytoplankton forms (cryptomonads, dinoflagellates, Phacotus, Trachelomonas) and Microcystis spp. Flagellated algae are often expected to be abundant when macrophytes are present (Borics et al., 2012), which is the case in the Sava Lake. However, the above-mentioned groups are also characterized by their tolerance to low phosphorus levels and have adaptive strategies for vertical migration in search of nutrients (Padisák et al., 2009; Žutinić et al., 2014), including chroococcalean species M. aeruginosa. Besides the fact that Microcystis spp. is a bloom-forming taxa which can dominate in late summer, this species is relatively poor competitor for light in comparison to other phytoplankton species, and also quite sensitive to reduced light availability (Borics et al., 2012). Furthermore, species included in this group are sensitive to prolonged mixing and prefer stable conditions (without disturbances) within the water column (Žutinić et al., 2014; Wood et al., 2017).

The second group included Codons Td, C, K, MP and X2, which showed the greatest correlation with precipitation and wind. This group unifies residents of shallow mesotrophic or eutrophic waters, as well as diatoms and meroplanktonic or periphytic species (such as Pseudanabaena catenata) belonging to coda $\mathrm{C}$ and MP. These two functional groups appear in turbid and mixed environment (Padisák et al., 2009), especially species from Codon MP. It is suspected that littoral diatoms included in this group emerge in the plankton community in cases when there is a high flushing rate (Žutinić et al., 2014). The appearance of Codon $\mathrm{K}$ in this group was not expected, however, it is mostly connected to D6.

The last group had the highest abundance in the late summer (especially in September) and was correlated with cloudiness. It was made up of organisms from Codons H1, F, $\mathrm{N}, \mathrm{X} 1, \mathrm{D}, \mathrm{J}$ and $\mathrm{P}$ that inhabit mixed and turbid environments, some of which $(\mathrm{X} 1, \mathrm{P}, \mathrm{J})$ are indicators of nutrient-enriched water (Padisák et al., 2009). In the last weeks of the study, Codon $\mathrm{F}$ was dominant in the community, followed by a large number of algae from Codon J. This specific assemblage developed after the 7th week of the study, when a second peak of wind and orthophosphate concentration were recorded, which leads to the conclusion that it also caused the mixing of the entire water column and enrichment from the sediment.

\subsection{Cyanobacterial groups in the Sava Lake}

A total of 30 cyanobacterial species, belonging to 19 genera, were microscopically identified in the Sava Lake during the summer period of 2014. Chroococcalean species dominated both in richness and biomass. The latter especially refers to $M$. aeruginosa (Codon $\mathrm{M}$ ), which mostly contributed to the cyanobacterial biomass.

As mentioned in the previous section, when concentrations of dissolved phosphorus are low, chroococcalean cyanobacteria are better competitors in comparison to other cyanobacterial groups and eukaryotic algae (Suthers and Rissik, 2008), while in the case of dissolved nitrogen limitation, heterocystous cyanobacteria are more successful. Besides nutrients, water temperature and stratification are very important factors for the development of cyanobacteria (Wood et al., 2017). In this regard, frequency and the intensity of wind and rainfall can play a significant role in the growth of cyanobacteria.

Even though there are few studies which deal with the issue concerning the effect of rainfall on cyanobacterial development (Wood et al., 2017), meteorological factors are considered important for cyanobacterial bloom formation (Yang et al., 2016b). In general, there are two possible outcomes when it comes to this issue. The research carried out by Yang et al. (2016b) on the shallow Lake Taihu, indicated that extreme weather events caused an increase in nutrient concentrations and led to extended cyanobacterial blooms. However, in their research, Wood et al. (2017) suggest that destratification, increased turbidity and dilution caused by such events could lead to a decrease in the cyanobacterial biomass, even a complete bloom collapse. This was in accordance with 
our research, as bloom formation did not happen despite the fact that M. aeruginosa was the dominant species in August.

In addition, a significant precondition for cyanobacterial bloom formation is low wind speed (Yang et al., 2016b), bearing in mind that a stable water column is necessary for buoyant cyanobacteria in order to regulate their position (Beaver et al., 2013). The results from this study clearly indicate that wind intensity played an important role in shaping the phytoplankton assemblages, especially by preventing cyanobacterial development and therefore posing a threat to environmental and public health. Thus, an understanding of the influence of meteorological variations is also important for the improvement of risk assessment strategies concerning recreational water bodies.

\section{Conclusion}

In general, the results of this study indicate that weatherinduced variations in the Sava Lake during the summer of 2014 also induced short-term changes in the composition of the phytoplankton community, which affected the successional pattern. Water influx from excessive rainfall probably caused the dilution of the phytoplankton biomass, while intensive wind initiated the mixing of the entire water column, which was most likely followed by the resuspension of dissolved phosphorus from the sediment. Such conditions created a turbid environment, which favoured the growth of species from Codon $\mathrm{F}$ and $\mathrm{J}$ in late summer, but also decreased possibility of the massive cyanobacterial development.

In this study, the growth of $M$. aeruginosa, a species of interest when it comes to public health, positively correlated with insolation, temperature and transparency, which is in accordance with previous studies. In general, the limited amount of dissolved phosphorus in the Sava Lake enabled $M$. aeruginosa better competitiveness comparing to other cyanobacterial taxa. However, weather conditions characterized by frequent rainfall and intensive wind did not permit bloom formation.

For that reason, understanding how the phytoplankton community responds to environmental pressures is not only a valuable asset for the improvement of water quality control management, but also for upgrading ecological models in times of rapid climate change.

Acknowledgments. This research was supported by the Ministry of Science and Technological Development, Republic of Serbia, Project No. ON 176020. We express our thanks to Institute of Public Health of Serbia "Dr Milan Jovanović Batut" for providing us chemical analysis. We are grateful to Grainne Boyle Orlic for language correction. Also, we express our gratitude to anonymous reviewer for useful comments on an earlier version of the manuscript.

\section{References}

Beaver JR, Casamatta DA, East TL, et al. 2013. Extreme weather events influence the phytoplankton community structure in a large lowland subtropical lake (Lake Okeechobee, Florida, USA), Hydrobiologia 709(1): 213-226.

Blaženčić J. 1995. Floristic characteristics of the makrophytic vegetation in Lake Savsko near Belgrade (Serbia, Yugoslavia),
Glasnik instituta za botaniku $i$ botaničke baste Univerziteta $u$ Beogradu 29: 167-173.

Bogatov VV, Fedorovskiy AS. 2016. Freshwater ecosystems of the southern region of the russian far east are undergoing extreme environmental change. Knowl Manag Aquat Ecosyst 417: 34.

Borics G, Tóthmérész B, Lukács BA, Várbíró G. 2012. Functional groups of phytoplankton shaping diversity of shallow lake ecosystems, Hydrobiologia 698(1): 251-262.

Bresciani M, Rossini M, Morabito G, et al. 2013. Analysis of withinand between-day chlorophyll-a dynamics in Mantua Superior Lake, with a continuous spectroradiometric measurement, Mar Freshw Res 64: 303-316.

Cellamare M, Lançon AM, Leitão M, Cerasino L, Obertegger U, Flaim G. 2016. Phytoplankton functional response to spatial and temporal differences in a cold and oligotrophic lake. Hydrobiologia 764 (1): 199-209.

Devi MB, Gupta S, Das T. 2016. Phytoplankton community of Lake Baskandi anua, Cachar District, Assam, North East India - an ecological study. Knowl Manag Aquat Ecosyst 417: 2.

EN 15204:2008. Water quality - guidance standard on the enumeration of phytoplankton using inverted microscopy (Utermöhl technique). Brussels: European Committee for Standardization.

Foundation for Environmental Education. 2014. The results of the Blue Flag International Jury [accessed on July 2014]. http://www. blueflag.global/beaches/.

Grabowska M, Górniak A, Krawczuk M. 2013. Summer phytoplankton in selected lakes of the East Suwałki Lakeland in relation to the chemical water parameters, Limnol Rev 13 (1): 21-29.

Häggqvist K, Lindholm T. 2012. Phytoplankton dynamics in a shallow lake dominated by common water milfoil, Inland Waters 2 (3): 137-146.

Hillebrand H, Durselen CDD, Kirschtel U, Pollingher T, Zohary T. 1999. Biovolume calculation for pelagic and benthic microalgae, $J$ Phycol 35: 403-424.

Honti M, Istvánovics V, Osztoics A. 2007. Stability and change of phytoplankton communities in a highly dynamic environment the case of large, shallow Lake Balaton (Hungary). Hydrobiologia 581: 225-240.

ISO 10260:1992. Water quality: measurement of biochemical parameters - spectrometric determination of the chlorophyll a concentration.

Laskar HS, Gupta S. 2013. Phytoplankton community and limnology of Chatla floodplain wetland of Barak valley, Assam, North-East India. Knowl Manag Aquat Ecosyst 411: 06.

Ma X, Wang Y, Feng S, Wang S. 2015. Vertical migration patterns of different phytoplankton species during a summer bloom in Dianchi Lake, China. Environ Earth Sci 74 (5): 3805-3814.

Martinovic-Vitanovic VM, Milankov VM, Kalafatic VI. 2010. First record of freshwater bryozoans (Bryozoa: Phylactolaemata) in the aquatic invertebrate fauna of Serbia. Limnol-Ecol Manag Inland Waters 40 (1): 73-81.

Mićković B, Nikčević M, Grozdić T, Pucar M, Hegediš A, Gačić Z. 2014. Ecological potential assessment of Sava Lake based on fish community composition: preliminary results. Water Res Manag 4 (3): $21-25$.

Padisák J, Crossetti O, Naselli-Flores L. 2009. Use and misuse in the application of phytoplankton functional classification: a critical review with updates. Hydrobiologia 621: 1-19.

Petrović AM. 2015. Challenges of torrential flood risk management in Serbia. J Geogr Inst 'Jovan Cvijic' SASA 65 (2): 131.

Ren Y, Pei H, Hu W, et al. 2014. Spatiotemporal distribution pattern of cyanobacteria community and its relationship with the environ- 
mental factors in Hongze Lake, China. Environ Monit Assess 186 (10): 6919-6933.

Reynolds CS. 1980. Phytoplankton assemblages and their periodicity in stratifying lake systems. Ecography 3 (3): 141-159.

Reynolds CS, Huszar V, Kruk C, Naselli-Flores L, Melo S. 2002. Towards a functional classification of the freshwater phytoplankton. J Plankton Res 24: 417-428.

Rhee GY, Gotham IJ. 1981. The effect of environmental factors on phytoplankton growth: temperature and the interactions of temperature with nutrient limitation. Limnol Oceanogr 26 (4): 635-648.

Rosen BH, St. Amand A. 2015. Field and laboratory guide to freshwater cyanobacteria harmful algal blooms for Native American and Alaska Native communities (no. 2015-1164). US Geological Survey, $44 \mathrm{p}$.

Serbian Regulation on the parameters of ecological and chemical status of surface waters and parameters of chemical status and quantitative status of ground waters. Official Gazette of the RS 74/ 2011.

Shannon CE, Weaver W. 1949. The mathematical theory of communication. Urbana: University of Illinois Press, $173 \mathrm{p}$.

Sun J, Liu D. 2003. Geometric models for calculating cell biovolume and surface area for phytoplankton. J Plankton Res 25: $1331-1346$

Suthers MI, Rissik D. 2008. Plankton - a guide to their ecology and monitoring for water quality. Colllingwood, VIC, Australia: CSIRO Publishing.

The Republic Hydrometeorological Institute of Serbia. 2014. Annual Bulletin for Serbia, year 2013. Belgrade: Department for Climate
Forecast, Information and Training, The Republic Hydrometeorological Service of Serbia.

The Republic Hydrometeorological Institute of Serbia. 2015. Annual Bulletin for Serbia, year 2014. Belgrade: Department for Climate Forecast, Information and Training, The Republic Hydrometeorological Service of Serbia.

Wood SA, Borges H, Puddick J, et al. 2017. Contrasting cyanobacterial communities and microcystin concentrations in summers with extreme weather events: insights into potential effects of climate change. Hydrobiologia 785 (1): 71-89.

Yang Y, Pettersson K, Padisák J. 2016a. Repetitive baselines of phytoplankton succession in an unstably stratified temperate lake (Lake Erken, Sweden): a long-term analysis. Hydrobiologia 764 (1): 211-227.

Yang Z, Zhang M, Shi X, Kong F, Ma R, Yu Y. 2016b. Nutrient reduction magnifies the impact of extreme weather on cyanobacterial bloom formation in large shallow Lake Taihu (China). Water Res 103: 302-310.

Znachor P, Zapomělova E, Reháková K, Nedoma J, Šimek K. 2008. The effect of extreme rainfall on summer succession and vertical distribution of phytoplankton in a lacustrine part of a eutrophic reservoir. Aquat Sci 70 (1): 77-86.

Zohary T, Padisák J, Naselli-Flores L. 2010. Phytoplankton in the physical environment: beyond nutrients, at the end, there is some light. Hydrobiologia 639: 261-269.

Žutinić P, Gligora-Udovič M, Kralj-Borojević K, Plenković-Moraj A, Padisák J. 2014. Morpho-functional classifications of phytoplankton assemblages of two deep karstic lakes. Hydrobiologia 740: $147-166$.

Cite this article as: Jovanović J, Trbojević I, Simić GS, Popović S, Predojević D, Blagojević A, Karadžić V. 2017. The effect of meteorological and chemical parameters on summer phytoplankton assemblages in an urban recreational lake. Knowl. Manag. Aquat. Ecosyst., 418, 48. 